\title{
Perilaku Pencarian Informasi Mengenai Kebijakan Sekolah Tatap Muka oleh Orang Tua Siswa di kota Malang
}

\author{
Kun Sila Ananda \\ Program Studi Pendidikan Sosiologi, Universitas Negeri Malang \\ Email:kun.ananda.fis@um.ac.id
}

\begin{abstract}
Abstrak
Belakangan ini Kemdikbud telah menetapkan kebijakan pelaksanaan sekolah tatap muka. Selain akademisi, orang tua menjadi pihak krusial dalam hal ini terutama berkaitan dengan pengambilan keputusan untuk mengizinkan anak mengikuti pelaksanaan sekolah tatap muka. Sebelum mengambil keputusan terlebih dahulu orang tua harus mereduksi berbagai ketidakpastian dan kurangnya informasi terkait kebijakan tersebut. Penelitian ini membahas mengenai perilaku pencarian informasi yang dilakukan orang tua terkait kebijakan sekolah tatap muka hingga proses pengambilan keputusan. Metode yang digunakan adalah survei deskriptif dengan teknik pengumpulan data melalui survei dan wawancara. Hasil penelitian menunjukkan bahwa orang tua melakukan pencarian informasi secara aktif dan pasif. Pihak sekolah (guru, wali kelas, kepala sekolah, dsb) menjadi sumber informasi yang paling sering dirujuk oleh orang tua siswa sekaligus dianggap sebagai sumber informasi yang paling terpercaya. Informasi yang dianggap paling penting oleh orang tua siswa adalah mengenai kesiapan sekolah dalam pelaksanaan pembelajaran tatap muka di masa pandemi. Adapun dalam pengambilan keputusan orang tua seringkali memanfaatkan sumber informasi melalui media daring dan diskusi bersama orang tua siswa lainnya. Mayoritas orang tua akan menunda pengambilan keputusan jika informasi yang didapatkan dirasa belum cukup, sementara di sisi lain orang tua juga dapat mengalami kegagalan pengambilan keputusan karena paparan informasi yang terlalu berlebihan.
\end{abstract}

Kata kunci : perilaku pencarian informasi; pengambilan keputusan; sekolah tatap muka; kebutuhan informasi; orang tua siswa

\section{Information Seeking Behavior on Face-to-face Learning Policy Among Students Parents in Malang City}

\begin{abstract}
Recently, the Ministry of Education and Culture has established a policy for implementing faceto-face schools. Regarding this policy, students' parents become a key point in order to make decisions to allow children to attend face-to-face schooling. Before decision making, parents must first reduce uncertainties and lack of information related to the policy. This study discusses the information-seeking behavior of parents related to face-to-face school policies and the decisionmaking. The method used is descriptive survey. Data collected through online surveys and interviews. The results showed that parents did the active and passive behavior on information seeking. The school (teachers, homeroom teachers, principals, etc.) is the most frequently referred source of information by parents and is considered the most trusted source of information. The most important information needed by parents is regarding the readiness of the school in the implementation of face-to-face learning during the pandemic. In decision-making process, parents often use information sources through online media and discussions with other parents. The majority of parents will delay decision making if the information obtained is deemed
\end{abstract}


insufficient, while on the other hand parents can also experience decision-making failure due to information overload.

Keywords : information-seeking behavior; decision making; face-to-face learning; information need; students' parents

\section{LATAR BELAKANG}

Pandemi Covid-19 di Indonesia belum berakhir. Memasuki awal tahun 2021, pemerintah justru mencatat peningkatan jumlah pasien terkonfirmasi positif Covid-19 setelah Natal dan Tahun Baru. Meski begitu, pemerintah memberikan sinyal untuk mulai menerapkan sekolah tatap muka. Faktanya, 13\% sekolah sudah melakukan pembelajaran tatap muka pada bulan November 2020 (Katadata.co.id, 2020). Jumlah sekolah yang memberlakukan pembelajaran tatap muka terus meningkat hingga $22 \%$ pada Maret 2021. Bahkan pada daerah yang masuk dalam zona hijau, tidak kurang dari 45\% sekolah melakukan pembelajaran tatap muka (Katadata.co.id, 2021).

Melihat kenaikan jumlah sekolah yang melakukan tatap muka ini, Menteri Pendidikan dan Kebudayaan Nadiem Makarim, berdasarkan SKB (Surat Keputusan Bersama) 4 Menteri, menetapkan bahwa pada pada bulan Juli 2021 semua sekolah harus sudah menerapkan pembelajaran tatap muka (Kontan.co.id, 2021).

Kebijakan yang baru muncul ini tentunya menjadi perhatian tak hanya bagi akademisi melainkan juga bagi orang tua siswa. Sejak lama, keterlibatan orang tua dalam pendidikan serta pembuatan keputusan terkait akademik anak telah dilihat sebagai sebuah keharusan (Wilcox, 1972). Keterlibatan orang tua juga terbukti mampu memberikan pengaruh posisif terhadap hasil pendidikan anak, terutama berkaitan dengan prestasi akademiknya (Anderson \& Minke, 2007). Dalam kasus kebijakan sekolah tatap muka ini, keterlibatan orang tua menjadi krusial sebab persetujuan orang tua menjadi penentu apakah anak boleh mengikuti pelaksanaan sekolah tatap muka atau tidak.

Pengambilan keputusan, seperti halnya yang dilakukan oleh orang tua untuk mengizinkan anak mengikuti pelaksanaan sekolah tatap muka, biasanya dilihat sebagai sebuah bentuk pilihan yang diambil dari beberapa alternatif yang ada. Dalam kasus ini, pilihan yang dimiliki orang tua adalah mengizinkan atau tidak mengizinkan anak untuk mengikuti sekolah tatap muka. Ketika seseorang dihadapkan pada pilihan, hal yang umum terjadi adalah pengambil keputusan harus mengumpulkan informasi terkait pilihan-pilihan yang ada. Hal ini agar tiap pilihan dapat dievaluasi dan dibandingkan satu sama lain untuk dapat diambil keputusan terbaik (Case, 2007). Berdasarkan pandangan ini, maka perilaku pencarian informasi tidak dapat dilepaskan dari proses pengambilan keputusan oleh orang tua siswa.

Artikel ini akan mencoba menjelaskan bagaimana perilaku pencarian informasi mengenai kebijakan sekolah tatap muka oleh orang tua siswa yang berujung pada proses pengambilan keputusan terkait persetujuan pelaksanaan pembelajaran sekolah tatap muka untuk anak mereka. Lebih lanjut, penelitian ini diharapkan juga dapat memberikan gambaran terkait aspek-aspek kebutuhan informasi orang tua siswa, kecenderungan pemilihan sumber informasi, serta tingkat kepercayaan terhadap sumber informasi.

Ketidakpastian merupakan konsep kunci dalam kajian perilaku pencarian informasi pengambilan keputusan, dan komunikasi (Kuhlthau dkk., 2008). Ketika berhadapan dengan munculnya kebijakan baru sekolah tatap muka, orang tua siswa 
dihadapkan pada banyaknya ketidakpastian. Dalam perspektif ilmu informasi, kebutuhan terhadap informasi dapat dipicu oleh tidak adanya pengetahuan atau kurangnya pemahaman mengenai suatu hal yang dibutuhkan untuk menyelesaikan masalah atau mencapai tujuan lainnya (Batley, 2007). Berawal dari banyaknya ketidakpastian serta kurangnya pengetahuan terkait pelaksanaan sekolah tatap muka, para orang tua kemudian berupaya melakukan pencarian informasi melalui berbagai sumber informasi yang tersedia.

Perilaku pencarian informasi muncul sebagai sebuah konsekuensi atas kebutuhan yang dirasakan dan disadari oleh pengguna informasi, di mana untuk memuaskan kebutuhannya, membuat tuntutan-tuntutan terhadap sumber-sumber informasi, yang dapat membuahkan hasil yang positif maupun negatif (Garg, 2016). Secara umum, perilaku pencarian informasi sendiri dapat didefinisikan sebagai aktivitas yang dilakukan oleh seseorang setelah mereka mengidentifikasi kebutuhan informasi mereka dan tindak lanjut dari informasi yang telah didapatkan. Sehingga perilaku pencarian informasi biasanya melibatkan beberapa aspek, yakni kebutuhan informasi, perilaku pencarian, media yang digunakan untuk mendapatkan informasi, serta tindak lanjut dari informasi yang telah didapatkan (Koja-Odongo \& Mostert, 2013).

Perilaku pencarian informasi telah menjadi subjek penelitian sejak 50 tahun terakhir. Beberapa pemikiran penting yang muncul dari penelitian-penelitian tersebut adalah munculnya beberapa model atau framework yang bisa digunakan untuk mengkaji perilaku pencarian informasi, antara lain model milik Ellis (1989), Kuhlthau (1993), dan Wilson (1997). Sementara Ellis dan Kuhlthau melihat perilaku pencarian informasi sebagai sebuah proses pemenuhan kebutuhan akan informasi, di mana seseorang secara aktif mengejar informasi, Wilson melihat perilaku pencarian informasi sebagai sebuah upaya penyelesaian masalah di mana pada akhirnya pencari informasi dapat mengalami keberhasilan dan kegagalan dalam upaya pemecahan masalahnya (Foster, 2004).

Wilson tidak hanya menekankan perilaku pencarian informasi sebagai aktivitas yang selalu aktif dan dilakukan dengan tujuan untuk mendapatkan sesuatu. Wilson berpendapat bahwa dalam kaitannya dengan ketidakpastian serta kebutuhan seseorang terhadap sebuah informasi, perilaku pencarian informasi dapat berupa tindakan aktif dan pasif (Wilson, 1999). Hal ini termasuk komunikasi tatap muka dengan orang lain, serta secara tidak langsung mendapatkan informasi, misalkan ketika menonton televisi atau berselancar di internet. Ketika melakukan aktivitas lain, seseorang bisa saja mendapatkan informasi yang ia butuhkan tanpa adanya keinginan atau niat untuk mencari informasi tersebut.

Adapun kajian mengenai perilaku pencarian informasi yang melibatkan orang tua telah dilakukan sebelumnya. Beberapa di antaranya adalah kajian mengenai kaitan antara gap pengetahuan dan pencarian informasi yang dilakukan orang tua mengenai penyakit hipospadias (Chan dkk., 2020). Hipopasdias merupakan kondisi bawaan bayi di mana lubang kencing ada pada bagian bawah organ. Kondisi ini membutuhkan operasi yang biasanya dilakukan sebelum usia 18 bulan. Penelitian ini mengidentifikasi adanya gap pengetahuan, kebutuhan informasi, serta perilaku pencarian informasi mengenai hipospadias oleh orang tua sebelum mereka mengambil keputusan untuk menyetujui tindakan operasi pada anak.

Penelitian lain yang melibatkan perilaku pencarian informasi orang tua berkaitan dengan pendidikan anak adalah penelitian yang mengkaji perilaku pencarian informasi 
orang tua imigran yang tinggal pada komunitas miskin Amerika Serikat terkait keputusan untuk memanfaatkan kebijakan memilih sekolah yang ditetapkan pemerintah Amerika Serikat (Assefa \& Stansbury, 2018). Bagi para orang tua imigran dengan keadaan ekonomi rendah, kebijakan pemilihan sekolah dapat menjadi salah satu cara untuk mendapatkan pendidikan berkualitas bagi anak mereka. Namun, penelitian ini mengungkap bahwa sedikit sekali orang tua imigran yang memanfaatkan kebijakan tersebut untuk anaknya. Di antara orang tua yang memanfaatkan kebijakan tersebut, mayoritas melakukan pencarian informasi sebelum memilih sekolah dengan bertanya pada teman dan melakukan kunjungan ke sekolah yang dituju.

Penelitian terkait perilaku pencarian informasi orang tua yang berkaitan dengan anak juga dilakukan oleh Crowley \& High. Dalam penelitiannya, Crowley mengkaji perilaku pencarian informasi mengenai pilihan karir dan pengembangan karir yang dilakukan oleh orang tua untuk memfasilitasi anak mereka yang memasuki usia dewasa muda. Crowley menemukan bahwa orang tua menjadi sumber informasi penting bagi anak yang memasuki usia dewasa muda berkaitan dengan keputusan mereka untuk pengembangan dan pemilihan karir (Crowley \& High, 2018). Karenanya, orang tua perlu terus memperbarui pengetahuan mereka mengenai pengembangan dan pemilihan karir untuk dapat meneruskan informasi tersebut pada anak mereka. Dalam pencarian informasi mengenai pengembangan karir, orang tua lebih banyak melakukan komunikasi tatap muka serta mencari informasi di internet.

Dari beberapa penelitian tersebut tampak bahwa keterlibatan orang tua pada kehidupan anak, terutama berkaitan dengan Kesehatan, pendidikan dan pengembangan diri anak menjadi faktor yang penting. Perilaku pencarian informasi oleh orang tua bukan hanya dimanfaatkan oleh diri mereka melainkan digunakan untuk kepentingan anak mereka, baik berupa penerusan informasi (Crowley \& High, 2018) maupun berupa pengambilan keputusan (Assefa \& Stansbury, 2018; Chan dkk., 2020).

Pada artikel ini, perilaku pencarian informasi yang dilakukan oleh orang tua juga berkaitan dengan pendidikan serta kesehatan anak yang berujung pada pengambilan keputusan untuk menyetujui atau tidak menyetujui pelaksanaan sekolah tatap muka yang akan diikuti oleh anak mereka.

\section{METODE PENELITIAN}

Penelitian ini menggunakan metode survei deskriptif. Metode survei deskriptif mencoba untuk menjelaskan atau mencatat kondisi atau sikap saat ini. Tujuannya adalah untuk menemukan situasi terkini dari sebuah situasi (Wimmer \& Dominick, 2011). Metode survei digunakan untuk penelitian yang melibatkan perilaku, opini, sikap, karakteristik, atau keyakinan partisipan (Neuman, 2014).

Dalam penelitian ini, survei deskriptif digunakan untuk mengetahui perilaku pencarian informasi terkait kebijakan sekolah tatap muka pada orang tua siswa. Adapun aspek yang akan diteliti yakni: kebutuhan informasi, sumber informasi, perilaku pencarian informasi, dan pengambilan keputusan.

Peneliti mengambil sampel sebanyak 50 partisipan yang dipilih menggunakan teknik purposive sampling. Partisipan dipilih menggunakan goodness kriteria, antara lain berdomisili di kota Malang, memiliki anak usia sekolah dan dalam waktu dekat anak akan terdampak kebijakan sekolah tatap muka.

Teknik pengumpulan data primer dilakukan melalui survei daring menggunakan Google Form. Sementara pengumpulan data sekunder dilakukan melalui wawancara baik 
secara langsung maupun melalui aplikasi chatting. Wawancara tidak dilakukan pada semua partisipan, melainkan hanya pada 5 partisipan secara random sampling berdasarkan kesediaan (volunteer) yang diberikan partisipan pada saat mengikuti survei.

Data akan dianalisis menggunakan teknik presentase dengan prosedur: pemeriksaan data, klasifikasi data, tabulasi data, distribusi frekuensi, penghitungan presentase, visualisasi dalam bentuk tabel atau diagram lingkaran, dan deskripsi data. Sementara data sekunder berupa hasil wawancara akan dianalisis secara induktif melalui prosedur: reduksi data, kategorisasi berdasarkan topik, penarikan kesimpulan, dan deskripsi data.

\section{HASIL DAN PEMBAHASAN}

Dari 50 orang tua yang mengikuti survei, 42 orang berjenis kelamin perempuan dan 8 orang laki-laki. Usia orang tua bervariasi antara 30 tahun hingga 55 tahun. Pendidikan terakhir orang tua bervariasi antara SMA hingga Master (S2) dengan jumlah mayoritas adalah Sarjana (S1). Mayoritas partisipan adalah ibu rumah tangga (18 orang), diikuti oleh ASN/PNS (12 orang), Guru (10 orang), dan sisanya adalah karyawan swasta serta wiraswasta. Adapun jenis kelamin anak dari partisipan hampir seimbang antara laki-laki dan perempuan, yakni perempuan berjumlah 21 anak dan laki-laki berjumlah 29 anak. Rentang usia anak antara 4 tahun hingga 17 tahun dengan jumlah terbanyak berusia antara 6-10 tahun yakni 26 anak. Adapun anak-anak tersebut mayoritas duduk di Sekolah Dasar (SD) sebanyak 30 anak, diikuti oleh jenjang SMP dan SMA sebanyak 8 anak, dan terakhir masih duduk di TK sebanyak 4 anak. Deskripsi karakteristik partisipan dapat dilihat pada tabel 1.

Tabel 1. Deskripsi Karakteristik Partisipan

\begin{tabular}{|c|c|c|}
\hline Deskripsi Karakteristik & $\begin{array}{c}\text { Jumlah } \\
(\mathbf{n})\end{array}$ & $\begin{array}{c}\text { Presentase } \\
(\%)\end{array}$ \\
\hline \multicolumn{3}{|l|}{ Jenis Kelamin orang tua } \\
\hline Perempuan & 42 & $84 \%$ \\
\hline Laki-laki & 8 & $16 \%$ \\
\hline \multicolumn{3}{|l|}{ Usia orang tua } \\
\hline $30-35$ th & 14 & $28 \%$ \\
\hline $36-40$ th & 14 & $28 \%$ \\
\hline $41-45$ th & 12 & $24 \%$ \\
\hline $46-50$ th & 4 & $8 \%$ \\
\hline $51-55$ th & 6 & $12 \%$ \\
\hline \multicolumn{3}{|l|}{$\begin{array}{l}\text { Pendidikan terakhir } \\
\text { orang tua }\end{array}$} \\
\hline SMA & 6 & $12 \%$ \\
\hline Diploma (D3) & 2 & $4 \%$ \\
\hline Sarjana (S1) & 36 & $72 \%$ \\
\hline Master (S2) & 6 & $12 \%$ \\
\hline \multicolumn{3}{|l|}{ Pekerjaan orang tua } \\
\hline Ibu rumah tangga & 18 & $36 \%$ \\
\hline Karyawan swasta & 4 & $8 \%$ \\
\hline Wirausaha & 6 & $12 \%$ \\
\hline Guru & 10 & $20 \%$ \\
\hline ASN/PNS & 12 & $24 \%$ \\
\hline Jenis kelamin anak & & \\
\hline
\end{tabular}




\begin{tabular}{lcc}
\hline Perempuan & 21 & $42 \%$ \\
Laki-laki & 29 & $58 \%$ \\
\hline Usia anak & & \\
$1-5$ th & 4 & $8 \%$ \\
$6-10$ th & 26 & $52 \%$ \\
$11-15$ th & 14 & $28 \%$ \\
$16-20$ th & 6 & $12 \%$ \\
\hline Jenjang sekolah anak & & \\
TK & 4 & $8 \%$ \\
SD & 30 & $60 \%$ \\
SMP & 8 & $16 \%$ \\
SMA & 8 & $16 \%$ \\
\hline
\end{tabular}

Sumber: Data Peneliti

Berkaitan dengan alasan orang tua melakukan perilaku pencarian informasi terkait kebijakan sekolah tatap muka, sekitar 31 partisipan (62\%) merasa tidak adanya informasi yang pasti mengenai topik tersebut, 13 (26\%) partisipan menjawab banyaknya informasi yang simpang siur terkait pelaksanaan sekolah tatap muka. Sementara 6 orang (12\%) merasa perlu mencari informasi karena mereka tidak memiliki preferensi atau pengetahuan mengenai topik tersebut.

Dilihat dari data tersebut, artinya perilaku pencarian informasi dipicu oleh adanya ketidakpastian yang dialami oleh orang tua. Selain itu, perilaku ini juga muncul karena banyaknya informasi yang simpang siur dan belum dapat dipastikan kebenarannya. Sebagian kecil partisipan mulai melakukan pencarian informasi karena tidak adanya pengetahuan pada diri mereka, sehingga mereka merasa perlu menambah pengetahuan mengenai hal tersebut.

Hasil ini sejalan dengan pandangan beberapa peneliti sebelumnya, yakni perilaku pencarian informasi biasanya dipicu oleh perasaan ketidakpastian, ambiguitas, dan rasa tidak nyaman ketika seseorang tidak memiliki informasi apapun mengenai sebuah masalah atau topik yang ia hadapi di kehidupan sehari-hari (Case, 2007). Selain itu, sebagian kecil partisipan menyadari bahwa mereka tidak memiliki informasi yang cukup mengenai pelaksanaan pembelajaran tatap muka di masa pandemi juga membuat orang tua berupaya untuk mencari informasi. Dalam hal ini artinya orang tua menyadari adanya gap pengetahuan yang saat ini mereka miliki dengan pengetahuan yang seharusnya mereka ketahui mengenai sekolah tatap muka sebelum membuat keputusan terkait izin pelaksanaan sekolah tatap muka untuk anak mereka.

Dari gambaran mengenai faktor pemicu perilaku pencarian informasi pada orang tua terkait pelaksaan sekolah tatap muka ini terlihat bahwa di era digital seperti saat ini, di mana ketersediaan informasi di media sekitar kita (baik melalui internet berupa media daring maupun sosial media, media massa cetak, dan lainnya) melimpah ruah, kesulitan untuk menemukan informasi yang valid menjadi faktor pemicu terbesar dalam perilaku pencarian informasi oleh orang tua. Selain itu, informasi yang datang secara masif dengan konten yang sangat bervariasi dapat menyebabkan pengguna media kewalahan dalam memilah-milah informasi (Schmitt et al., 2018). Hal ini pula yang dialami oleh orang tua ketika mereka dihadapkan dengan informasi terkait pelaksanaan tatap muka yang muncul dalam berbagai versi. Sementara orang tua tidak dapat menemukan informasi mana yang paling valid dan resmi dari pemerintah. 
Di sisi lain, faktor lain yang mendukung munculnya perilaku pencarian informasi adalah adanya ketidaktahuan serta kesadaran akan gap pengetahuan yang dimiliki orang tua mengenai informasi terkait. Hal ini sejalan dengan teori pencarian informasi yang diungkapkan oleh Batley, di mana perilaku pencarian informasi biasanya diawali oleh ketidaktahuan oleh pelaku terhadap suatu hal (Batley, 2007). Meski begitu, berbeda dengan penemuan dalam penelitian Chan dkk. (2020) di mana gap pengetahuan merupakan faktor utama yang memicu perilaku pencarian informasi, dalam kasus ini gak pengetahuan menjadi faktor pendukung. Sementara faktor kunci adalah banyaknya informasi yang diterima oleh orang tua (baik melalui internet, media massa, dsb) yang terlalu bervariasi dan sulit divalidasi.

Dalam upaya pencarian informasi, 33 partisipan (66\%) mengaku melakukan pencarian secara aktif. Sekitar 4 partisipan (8\%) mengaku mendapatkan informasi secara pasif, sementara 13 partisipan (26\%) partisipan melakukan kombinasi keduanya. Partisipan yang mendapatkan informasi secara pasif salah satunya menjelaskan bahwa seringkali informasi ia dapatkan secara tidak sengaja saat menggunakan media sosial.Sebagaimana penuturan salah satu informan

"Saya mengetahui informasi mengenai sekolah tatap muka justru melalui Facebook, pada link yang di-share oleh salah satu teman." (ES)

Salah satu partisipan yang melakukan kombinasi keduanya (aktif dan pasif) menjelaskan bahwa seringkali ia mendapatkan informasi secara pasif dari grup chat orang tua siswa.

"Kalau secara pasif biasanya dapat dari grup Whatsapp, dari wali murid lain yang share informasi." (AM)

Setelah mendapatkan informasi tersebut, biasanya ia kemudian melakukan pencarian informasi melalui media lain. Motivasi dari pencarian informasi lainnya setelah dipicu adanya informasi yang didapatkan secara pasif tersebut adalah untuk mencari informasi lebih lanjut atau melakukan konfirmasi atas informasi yang telah dibagikan di grup chat.

Hasil ini sejalan dengan pandangan Wilson mengenai cara seseorang melakukan pencarian informasi, yakni pencarian informasi juga dapat berupa tindakan pasif di mana seseorang mendapatkan informasi secara tidak sengaja atau tanpa terlebih dahulu berniat mencari informasi (Wilson, 1999). Perilaku pencarian informasi yang aktif dilakukan dengan secara sadar mencari informasi melalui berbagai sumber informasi seperti media massa, internet, sosial media, maupun dengan bertanya pada teman, anggota keluarga, atau dokter (tenaga medis). Sementara hasil penelitian ini menunjukkan bahwa Sebagian kecil orang tua melakukan pencarian informasi secara pasif. Artinya bahwa mereka hanya menerima informasi dari berbagai sumber tanpa terlebih dahulu secara sadar melakukan pencarian informasi.

\section{Kebutuhan Informasi}

Kebutuhan informasi dapat diartikan sebagai keinginan individu atau kelompok untuk mendapatkan informasi demi memenuhi kebutuhan sadar dan tidak sadarnya. Kebutuhan informasi juga mengacu pada pemahaman dan kesadaran dalam diri seseorang bahwa ada sesuatu yang tidak mereka miliki yang dapat dipenuhi dengan menemukan informasi tersebut (Kumar, 2015).

Hasil survei menunjukkan beberapa topik informasi yang dibutuhkan oleh orang tua terkait dengan pelaksanaan sekolah tatap muka. Topik yang paling banyak dipilih adalah informasi mengenai protokol kesehatan yang diterapkan di sekolah sebanyak 42 
orang. Selain itu, banyak orang tua yang mencari informasi mengenai kesiapan sekolah melaksanakan sekolah tatap muka sebanyak 40 orang. Sementara itu, 14 orang membutuhkan informasi terkait besarnya risiko anak terpapar Covid-19 di sekolah, dan 26 orang membutuhkan informasi mengenai sistematika pelaksanaan sekolah tatap muka. Termasuk di dalamnya adalah 2 orang yang ingin mengetahui durasi pelaksanaan tatap muka (lihat tabel 2).

Tabel 2. Kebutuhan Informasi

\begin{tabular}{lcc}
\hline \multicolumn{1}{c}{ Jenis Informasi } & $\begin{array}{c}\text { Jumlah } \\
(\mathbf{n})\end{array}$ & $\begin{array}{c}\text { Presentase } \\
(\%)\end{array}$ \\
\hline $\begin{array}{l}\text { Protokol Kesehatan yang } \\
\text { diterapkan di sekolah }\end{array}$ & 42 & $84 \%$ \\
\hline $\begin{array}{l}\text { Risiko anak terpapar } \\
\text { Covid-19 di sekolah }\end{array}$ & 14 & $28 \%$ \\
\hline $\begin{array}{l}\text { Kesiapan sekolah } \\
\text { melaksanakan } \\
\text { pembelajaran tatap muka }\end{array}$ & 40 & $80 \%$ \\
\hline $\begin{array}{l}\text { Sistematika pelaksanaan } \\
\text { sekolah tatap muka }\end{array}$ & 26 & $52 \%$ \\
\hline \multicolumn{1}{c}{ Sumber: Data Primer Peneliti }
\end{tabular}

Sumber: Data Primer Peneliti

Setelah mengidentifikasi topik-topik informasi apa saja yang dibutuhkan, selanjutnya orang tua menyeleksi topik-topik tersebut untuk menentukan topik mana yang paling penting serta paling banyak dicari oleh orang tua. Hasil survei menunjukkan bahwa mayoritas partisipan, sebanyak 17 orang, paling banyak mencari informasi terkait kesiapan sekolah melaksanakan pembelajaran tatap muka. Diikuti oleh informasi terkait protokol Kesehatan yang diterapkan di sekolah sebanyak 14 orang. Adapun 12 orang memilih topik mengenai sistematika pelaksanaan sekolah tatap muka sebagai informasi yang paling penting, dan sisanya sebanyak 7 orang lebih fokus pada risiko anak terpapar Covid-19 di sekolah. Prosentase kebutuhan informasi yang dianggap paling penting dapat dilihat pada Gambar 1.

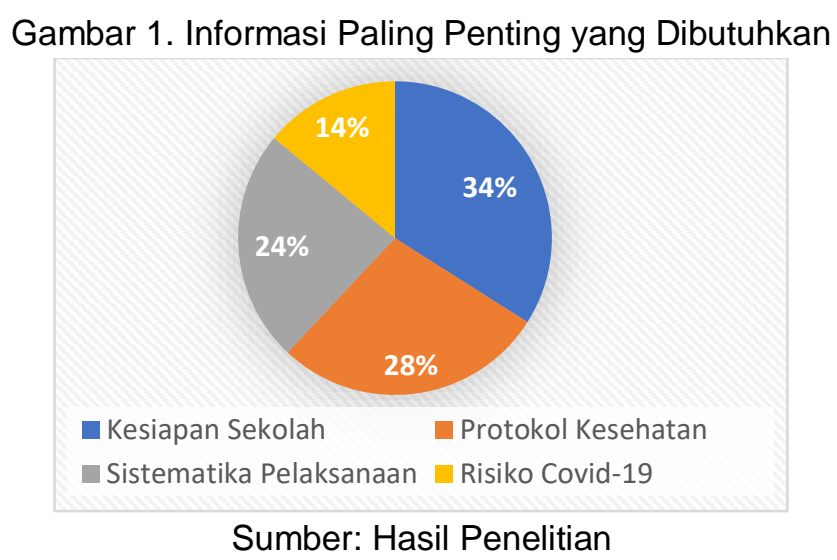

Kesehatan biasanya menjadi fokus utama dalam perilaku pencarian informasi oleh orang tua. Dalam keadaan biasa, secara umum topik utama yang akan dicari oleh orang tua dalam perilaku pencarian informasi adalah mengenai Kesehatan anak, diikuti dengan perkembangan anak, dan sekolah atau Pendidikan (Nicholas \& Marden, 1998). 
Meski begitu, pada hasil penelitian di atas, topik yang berkaitan murni dengan kesehatan seperti risiko anak terkena covid-19 memiliki presentase yang paling kecil yaitu $14 \%$.

Pada hasil di atas, justru terlihat bahwa informasi terkait kesiapan sekolah serta protokol keseharan apa yang akan dijalankan di sekolah selama pembelajaran tatap muka menjadi hal penting yang dicari oleh orang tua. Dengan kata lain, orang tua berupaya mencari informasi untuk memastikan keamanan anak ketika melakukan pembelajaran secara tatap muka dan apakah anak mereka akan cukup terlindungi saat belajar di sekolah selama pandemi berlangsung. Hal ini sejalan dengan hasil penelitian Avery dan Park yang menunjukkan bahwa sikap protektif orang tua seringkali mendominasi ketika mereka mencari informasi untuk anak di masa pandemi (Avery \& Park, 2021). Selama masa pandemi, perilaku pencarian informasi orang tua tidak berfokus pada diri mereka sendiri melainkan pada anak yang bersifat dependen pada diri mereka, sehingga pencarian informasi seringkali difokuskan untuk melindungi anak. Dalam hal ini, protokol kesehatan yang akan dilaksanakan di sekolah serta sejauh mana sekolah siap melaksanakan pembelajaran tatap muka menjadi topik yang penting untuk diketahui oleh orang tua.

\section{Sumber Informasi}

Pencarian informasi dapat dilakukan melalui banyak sumber informasi, baik sumber informasi formal maupun informal. Adapun dalam penelitian ini, sumber informasi dikategorikan menjadi beberapa kelompok, antara lain media daring, media sosial, anggota keluarga/saudara, pihak sekolah, sesama orang tua siswa, dan dokter atau tenaga medis.

Berdasarkan hasil survei, kebanyakan orang tua menggunakan lebih dari satu sumber untuk mencari informasi yang diperlukan. Sumber informasi yang paling banyak digunakan adalah dari pihak sekolah (baik guru, wali kelas, kepala sekolah, dan lainnya) yaitu 41 orang. Sumber informasi terbanyak kedua adalah media sosial (Facebook, Instagram, Twitter, dan lainnya) sebanyak 29 orang. Selanjutnya, media daring yang dipilih oleh 23 orang, sesama orang tua yang dipilih oleh 11 orang, dan anggota keluarga yang dipilih 9 orang. Adapun 8 orang memilih dokter/tenaga medis sebagai sumber informasi. Prosentase penggunaan sumber informasi dapat dilihat pada tabel 3.

Tabel 3. Sumber Informasi Wali

\begin{tabular}{lcc}
\hline \multicolumn{1}{c}{ Sumber Informasi } & $\begin{array}{c}\text { Jumlah } \\
(\mathbf{n})\end{array}$ & $\begin{array}{c}\text { Presentase } \\
(\boldsymbol{\%})\end{array}$ \\
\hline $\begin{array}{l}\text { Media daring } \\
\text { (Kompas.com, } \\
\text { Tribunnews.com, website, } \\
\text { dsb) }\end{array}$ & 23 & $46 \%$ \\
\hline $\begin{array}{l}\text { Media Sosial (Facebook, } \\
\text { Instagram, Twitter, dsb( }\end{array}$ & 29 & $58 \%$ \\
\hline Anggota Keluarga/Saudara & 9 & $18 \%$ \\
\hline $\begin{array}{l}\text { Pihak Sekolah (Guru, Wali } \\
\text { Kelas, Kepala Sekolah, } \\
\text { dsb) }\end{array}$ & 41 & $82 \%$ \\
\hline Sesama Orang Tua Siswa & 11 & \\
\hline Dokter/Tenaga Medis & 8 & $16 \%$ \\
\hline
\end{tabular}


Dari beberapa sumber informasi tersebut, sumber informasi yang paling sering digunakan oleh orang tua adalah pihak sekolah (Guru, Wali Kelas, Kepala Sekolah, dsb) sebanyak 24 orang. Diikuti oleh media sosial (Facebook, Instagram, Twitter, dsb) sebanyak 15 orang. Sebanyak 11 orang memilih media daring sebagai sumber informasi yang paling sering digunakan. Sementara sumber informasi yang paling jarang digunakan adalah anggota keluarga/saudara, sesama orang tua siswa, atau dokter. Sementara itu, sumber informasi yang dianggap paling banyak memberikan informasi pada orang tua antara lain pihak sekolah yang dipilih oleh 19 orang, media daring yang dipilih oleh 18 orang, media sosial yang dipilih oleh 6 orang, sesama orang tua siswa yang dipilih oleh 5 orang, dan dari dokter yang dipilih oleh 2 orang. Prosentase sumber informasi yang paling sering digunakan dan dianggap paling banyak memberikan informasi dapat dilihat pada tabel 4.

Tabel 4. Sumber Informasi yang Sering digunakan dan Paling Banyak Memberikan Informasi

\begin{tabular}{|c|c|c|c|c|}
\hline \multicolumn{3}{|c|}{$\begin{array}{c}\text { Sumber Informasi Paling Sering } \\
\text { Digunakan }\end{array}$} & \multicolumn{2}{|c|}{$\begin{array}{l}\text { Sumber Informasi yang paling } \\
\text { Banyak Memberikan Informasi }\end{array}$} \\
\hline Sumber Informasi & $\begin{array}{l}\text { Jumlah } \\
\text { (n) }\end{array}$ & $\begin{array}{c}\text { Presentase } \\
(\%)\end{array}$ & $\begin{array}{c}\text { Jumlah } \\
\text { (n) }\end{array}$ & $\begin{array}{l}\text { Presentase } \\
(\%)\end{array}$ \\
\hline $\begin{array}{l}\text { Media daring } \\
\text { (Kompas.com, } \\
\text { Tribunnews.com, } \\
\text { website, dsb) }\end{array}$ & 11 & $22 \%$ & 18 & $36 \%$ \\
\hline $\begin{array}{l}\text { Media Sosial } \\
\text { (Facebook, } \\
\text { Instagram, Twitter, } \\
\text { dsb( }\end{array}$ & 15 & $30 \%$ & 6 & $12 \%$ \\
\hline $\begin{array}{l}\text { Anggota } \\
\text { Keluarga/Saudara }\end{array}$ & 0 & $0 \%$ & 0 & $0 \%$ \\
\hline $\begin{array}{l}\text { Pihak Sekolah } \\
\text { (Guru, Wali Kelas, } \\
\text { Kepala Sekolah, } \\
\text { dsb) }\end{array}$ & 24 & $48 \%$ & 19 & $38 \%$ \\
\hline $\begin{array}{l}\text { Sesama Orang Tua } \\
\text { Siswa }\end{array}$ & 0 & $0 \%$ & 5 & $10 \%$ \\
\hline $\begin{array}{l}\text { Dokter/Tenaga } \\
\text { Medis }\end{array}$ & 0 & $0 \%$ & 2 & $4 \%$ \\
\hline
\end{tabular}

Dari data di atas didapatkan gambaran sumber informasi mana yang paling sering digunakan oleh orang tua mencari informasi secara aktif. Terlihat bahwa pihak sekolah merupakan rujukan utama yang terlebih dahulu dituju oleh orang tua siswa ketika mereka membutuhkan informasi terkait pelaksanaan sekolah tatap muka.

Sementara itu sumber informasi yang paling banyak memberikan informasi menunjukkan media apa saja yang memungkinkan munculnya informasi tanpa harus didahului oleh perilaku aktif untuk mencari informasi. Hasilnya menunjukkan bahwa pihak sekolah menjadi sumber informasi yang banyak memberikan informasi, diikuti oleh media daring, media sosial, dan sesama orang tua siswa. Bentuk informasi yang berasal dari pihak sekolah salah satunya berupa pengumuman. Sementara informasi pada media daring dan media sosial memungkinkan partisipan mendapatkan informasi secara 
pasif ketika partisipan menggunakannya untuk kepentingan lain. Adapun informasi dari orang tua siswa lainnya dapat berupa informasi yang dibagikan melalui grup chat.

Berkaitan dengan tingkat kepercayaan kepada sumber informasi, hasil survei menunjukkan bahwa pihak sekolah menjadi sumber informasi yang paling dipercayai oleh orang tua, yakni $58 \%$. Diikuti oleh media daring yang dipilih oleh $24 \%$ orang tua siswa. Selain itu, dokter menjadi sumber informasi terpercaya ketiga dengan $12 \%$, dan terakhir media sosial sebanyak $6 \%$. Sumber informasi dari anggota keluarga/saudara dan sesama orang tua siswa dianggap tidak dapat sepenuhnya dipercaya. Tingkat kepercayaan pada sumber informasi dapat dilihat melalui Gambar 2.

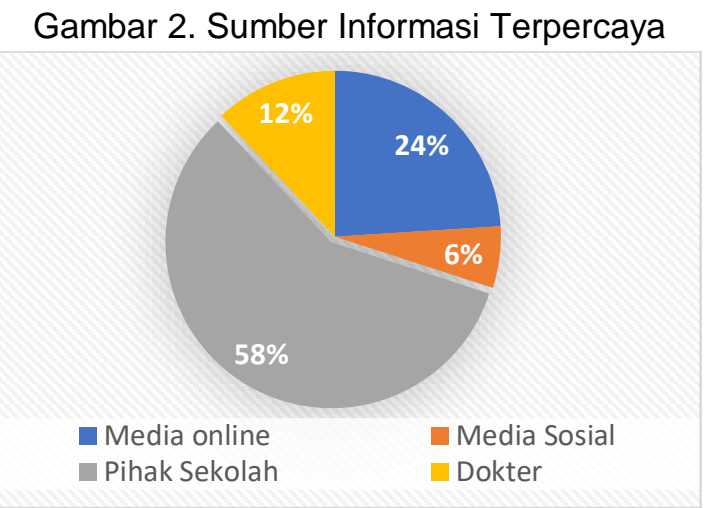

Hasil yang menunjukkan sumber informasi apa yang paling banyak digunakan oleh orang tua terkait pelaksanaan sekolah tatap muka ini cukup menarik, sebab terlihat bahwa sumber informasi yang paling banyak digunakan dan dianggap paling banyak memberikan informasi adalah pihak sekolah (baik Kepala Sekolah, Guru, Wali Murid, $\mathrm{dsb}$ ), dengan internet (yaitu media daring dan media sosial) sebagai sumber informasi kedua. Namun sebaliknya, dalam hal kepercayaan terhadap validitas informasi, sumber informasi internet terutama media sosial memiliki tingkat kepercayaan yang paling rendah dibandingkan dengan informasi dari pihak sekolah yang dinilai paling valid dan bisa dipercaya.

Berdasarkan hasil tersebut, terlihat bahwa bagi orang tua efikasi informasi yang berasal dari pihak sekolah lebih tinggi dibandingkan dengan efikasi informasi yang didapatkan dari internet seperti media sosial dan media daring. Konsep efikasi informasi atau berita (news efficacy) sendiri diartikan sebagai kepercayaan diri seseorang mengenai sejauh mana ia bisa mendapatkan informasi atau berita yang ia butuhkan dan dapat ia gunakan (Park, 2019). Dalam hal ini, orang tua memiliki efikasi diri yang lebih besar metika mereka menggunakan pihak sekolah sebagai sumber informasi.

Sebaliknya, orang tua siswa memiliki kepercayaan yang lebih kecil terhadap informasi yang mereka dapatkan melalui media sosial. Hal ini berkaitan dengan efikasi media yang dimiliki oleh orang tua terhadap media sosial dan media daring. Efikasi media (media efficacy) diartikan sebagai kepercayaan diri seseorang terhadap kemampuan mereka untuk menggunakan dan mengoperasikan media untuk memenuhi kebutuhan informasi yang mereka miliki (Hofstetter dkk., 2001). Tingginya efikasi media berarti bahwa seseorang percaya akan kemampuan mereka dalam mengoperasikan dan menggunakan media sehingga mereka akan mendapatkan hasil yang positif dan maksimal dari penggunaan tersebut. Dalam kasus ini, terlihat bahwa efikasi media (dalam hal ini media sosial dan media daring) yang dimiliki orang tua siswa rendah, 
sehingga mereka tidak memilih untuk menggunakan media sosial dan media daring sebagai sumber informasi utama. Efikasi media juga berkaitan dengan kemampuan seseorang untuk memilah informasi, yang mana dalam kasus ini orang tua siswa mengalami kesulitan memilah informasi yang masif serta beragam yang mereka dapatkan dari media sosial maupun media daring. Hal ini terlihat dari rendahnya tingkat kepercayaan orang tua terhadap media sosial dan media daring, yang menunjukkan bahwa orang tua tidak memiliki kepercayaan diri atas kemampuan mereka untuk memilah informasi yang valid dan yang merupakan hoax ketika mendapatkan informasi dari internet.

\section{Perilaku Pencarian Informasi}

Perilaku pencarian informasi membahas mengenai cara apa yang dilakukan oleh orang tua siswa untuk mencari informasi. Selain itu juga menjelaskan tentang apa yang dilakukan oleh orang tua setelah mendapatkan informasi yang dibutuhkan.

Adapun cara mencari informasi dikategorikan menjadi beberapa cara, yakni dengan bertanya langsung (baik pada pihak sekolah atau anggota keluarga), melalui internet (media daring dan media sosial), melakukan konsultasi dengan dokter atau tenaga medis, dan berdiskusi bersama orang tua siswa lainnya. Presentase mengenai beberapa cara mencari informasi yang dilakukan orang tua bisa dilihat pada tabel 5 .

Tabel 5. Cara Mencari Informasi

\begin{tabular}{lcc}
\hline Cara Mencari Informasi & $\begin{array}{c}\text { Jumlah } \\
(\mathbf{n})\end{array}$ & $\begin{array}{c}\text { Presentase } \\
(\boldsymbol{\%})\end{array}$ \\
\hline Bertanya langsung & 35 & $70 \%$ \\
\hline Menggunakan internet & 31 & $62 \%$ \\
\hline Konsultasi dengan dokter & 6 & $36 \%$ \\
\hline $\begin{array}{l}\text { Berdiskusi dengan orang } \\
\text { tua siswa lainnya }\end{array}$ & 23 & $46 \%$ \\
\hline
\end{tabular}

Beberapa penelitian mengemukakan bahwa orang tua seringkali lebih banyak menggunakan sumber informasi yang bersifat personal seperti bertanya langsung dengan tenaga professional sebagai sumber informasi utama mereka (Lwoga \& Mosha, 2013). Hal ini juga tercermin dalam penelitian ini, di mana dari tabel 5 di atas terlihat bahwa kebanyakan orang tua mencari informasi dengan bertanya langsung pada professional. Pada penelitian ini professional yang dimaksud adalah yang berkaitan dengan sekolah anak, yakni pihak sekolah seperti Kepala Sekolah, Guru, Wali Murid, dsb. Sementara berkaitan dengan risiko Kesehatan, terlihat juga banyak Sebagian orang tua memilih untuk berkonsultasi langsung dengan tenaga professional yakni dokter/dokter keluarga untuk mencari informasi.

Selain dengan bertanya langsung, orang tua juga menggunakan internet untuk mencari informasi yang dibutuhkan. Hal ini sejalan dengan dengan penelitian lainnya di mana saat ini jumlah orang tua yang menggunakan internet untuk mencari informasi semakin meningkat, salah satunya adalah informasi tentang kesehatan anak (Plantin \& Daneback, 2009). Kenaikan jumlah orang tua yang menggunakan internet sebagai sumber informasi ini terutama banyak terjadi di negara berkembang (Al-Ghamdi \& Moussa, 2012). Informasi yang didapatkan dari internet digunakan sebagai informasi 
sekunder untuk melengkapi informasi yang mereka dapatkan dari tenaga professional secara langsung.

Berdiskusi dengan orang tua siswa lainnya juga dianggap sebagai salah satu cara mendapatkan informasi. Jika menghubungkan hasil ini dengan hasil sebelumnya terdapat anomali dimana orang tua jarang sekali menggunakan orang tua siswa lainnya sebagai sumber informasi. Bahkan orang tua tidak menilai orang tua siswa lainnya sebagai sumber informasi yang terpercaya, dengan perolehan $0 \%$ pada kategori survei sebelumnya. Meski begitu pada perilaku pencarian informasi ditemukan bahwa orang tua siswa menggunakan diskusi bersama orang tua lainnya untuk mendapatkan informasi.

Hasil wawancara menunjukkan bahwa diskusi bersama orang tua siswa lainnya adalah salah satu cara yang digunakan untuk mendapatkan informasi, namun cara ini tidak dilakukan sebagai cara pencarian informasi tahap awal. Diskusi biasanya dilakukan Ketika orang tua telah memiliki cukup informasi dari sumber lainnya untuk kemudian dibicarakan bersama orang tua lain untuk mendapatkan informasi-informasi tambahan. Salah satu informasi tambahan biasanya berkaitan dengan pendapat orang tua siswa lainnya terkait informasi yang telah didapatkan.Di sisi lain, ada pula partisipan yang menjelaskan bahwa terkadang ia menghubungi wali kelas untuk mendapatkan informasi tambahan atau mengonfirmasi informasi yang ia dapatkan di media daring ataupun media sosial.

"Setelah membaca berita, kadang saya tanya pada wali kelasnya apakah (informasi) itu benar. Atau apakah (informasi tersebut) sudah akan diterapkan di sekolah anak saya. Karena biasanya sudah ramai di tempat lain tapi di sekolah anak saya belum." (NT)

Dari pernyataan tersebut terlihat bahwa selain melakukan verifikasi terhadap informasi yang didapatkan dari sumber informasi lainnya (media daring dan media sosial), orang tua juga mencari informasi tambahan yang lebih relevan dengan kehidupannya, atau informasi yang mungkin akan berdampak pada dirinya. Selain itu, proses pemilihan sumber informasi tampaknya tidak berkaitan dengan tingkat kepercayaan orang tua terhadap sumber informasi.

Proses pencarian informasi pun melibatkan penggunaan sumber informasi secara bergantian dan terus-menerus hingga sumber informasi dirasa cukup. Dalam hal ini, sumber informasi yang dianggap paling terpercaya oleh orang tua dapat menjadi sumber informasi pertama yang dirujuk oleh orang tua ataupun menjadi sumber informasi terakhir yang digunakan untuk memverifikasi informasi yang didapatkan melalui sumber-sumber informasi lainnya.

\section{Pengambilan Keputusan}

Di akhir survei, peneliti menanyakan pada partisipan terkait pengambilan keputusan yang mereka lakukan berkaitan dengan kebijakan sekolah tatap muka. Mayoritas orang tua, sebanyak 31 orang (62\%) menyatakan setuju terhadap pelaksanaan sekolah tatap muka, sementara 4 orang (8\%) menyatakan tidak setuju. Adapun 13 orang lainnya (26\%) masih ragu-ragu untuk memutuskan sikap terkait kebijakan sekolah tatap muka.

Pengambilan keputusan dalam keterkaitannya dengan kebijakan sekolah tatap muka dapat dilihat melalui model pencarian informasi untuk kehidupan sehari-hari (Everyday Life Information Seeking). Meski Savolainen mengaitkan model ELIS ini dengan pengambilan keputusan yang dilakukan oleh orang sehari-hari berkaitan dengan 
hal-hal sederhana dalam keseharian seperti masalah kesehatan, hobi, dan lainnya (Case, 2007), namun model ini juga bisa digunakan untuk melihat pengambilan keputusan yang dilakukan orang tua berkaitan dengan pendidikan anaknya (G. Assefa \& Stansbury, 2018).

Pada model ini, keputusan yang diambil mengenai persetujuan orang tua terkait keikutsertaan anak mereka dalam sekolah tatap muka dilihat sebagai keputusan yang harus dibuat pada satu titik di kehidupan mereka. Salah satu aspek mendasar dalam proses pembuatan keputusan adalah berkurangnya ketidakpastian akan keadaan atau pilihan-pilihan yang ada. Sementara ilmuwan seringkali berasumsi bahwa ketidakpastian dapat dikurangi dengan bertambahnya informasi yang didapatkan. Artinya kecukupan informasi seharusnya menjadi hal yang penting dalam pembuatan keputusan.

Namun dari hasil survei didapatkan bahwa sekitar 37 orang (74\%) beranggapan bahwa pencarian informasi sebanyak-banyaknya sangat penting dilakukan sebelum membuat keputusan. Sementara 13 orang lainnya $(26 \%)$ beranggapan bahwa pencarian informasi dapat dihentikan ketika informasi yang didapatkan sudah cukup mendukung keputusan yang akan diambil.

Melalui wawancara didapatkan bahwa beberapa orang tua seringkali merasa bingung ketika jumlah informasi yang didapatkan dirasa terlalu banyak. Artinya, jumlah informasi yang banyak tidak selalu berbanding lurus dengan pengurangan ketidakpastian. Semakin banyak informasi terkadang juga dapat menyebabkan informasi yang berlebihan (information overload) yang justru berujung pada bertambahnya ketidakpastian.

Berlebihnya informasi (information overload) terjadi ketika seseorang dihadapkan pada informasi yang lebih banyak daripada yang mampu mereka proses. Paparan terhadap informasi yang terlalu banyak dapat menyebabkan seseorang mengalami disorientasi hingga dapat secara negative mempengaruhi kemampuan seseorang untuk mengambil keputusan (Bawden \& Robinson, 2009).

Hal ini juga terlihat dari hasil survei terhadap orang tua siswa terkait pengambilan keputusan jika kebutuhan informasi belum terpenuhi. Mayoritas orang tua (46\%) menyatakan akan menunda pengambilan keputusan jika informasi yang didapatkan dirasa belum cukup. Sementara $42 \%$ menyatakan akan mengikuti keputusan pihak berwenang (pemerintah atau pihak sekolah) atau kelompok (orang tua siswa lainnya) jika informasi yang didapatkan belum cukup. Sementara $12 \%$ menyatakan akan tetap mengambil keputusan meski merasa belum mendapatkan informasi yang cukup karena merasa bahwa pencarian informasi tidak akan ada habisnya. Presentase mengenai sikap pengambilan keputusan orang tua Ketika informasi dirasa belum mencukupi dapat dilihat pada gambar 3 .

Dari hasil tersebut terdapat sebuah kecenderungan yang menarik berkaitan dengan tingginya orang tua yang menyatakan akan mengikuti keputusan pihak berwenang atau keputusan kelompok. Hal ini menunjukkan adanya pergeseran pengambil keputusan dari individu menjadi kelompok. Salah satu alasan partisipan melakukan hal ini adalah adanya asumsi bahwa kelompok dan pihak berwenang memiliki lebih banyak informasi dan pengetahuan terkait permasalahan yang ada (dalam hal ini pelaksanaan sekolah tatap muka) dibandingkan dirinya sendiri. Hasil ini bisa diartikan sebagai sebuah kegagalan di mana proses pengumpulan informasi tidak berdampak pada berkurangnya ketidakpastian dan bertambahnya keyakinan seseorang 
untuk mengambil keputusan berdasarkan informasi atau pengetahuan yang telah didapatkan.

Gambar 3. Sikap Pengambilan Keputusan Ketika Informasi Belum Mencukupi

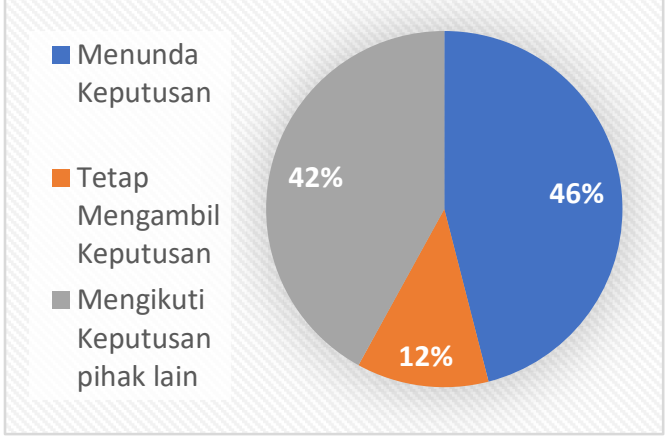

Kegagalan dalam perilaku pencarian informasi sebelumnya telah diungkapkan oleh Wilson, di mana pada akhirnya pencari informasi tidak mampu memecahkan permasalahan yang dihadapinya meski telah mendapatkan informasi dari proses pencarian informasi yang dilakukannya (Foster, 2004). Dalam hal ini salah satu penyebabnya adalah berlebihnya informasi (information overload) yang dialami oleh orang tua. Ketidakmampuan orang tua untuk memilah informasi atau mendapatkan informasi yang mereka butuhkan untuk membuat keputusan berkaitan dengan izin yang akan mereka berikan pada anak dalam pelaksanaan sekolah tatap muka membuat mereka tidak mengambil keputusan dan menyerahkan proses pengambilan keputusan terhadap pihak lain.

\section{KESIMPULAN}

Berkaitan dengan kebijakan sekolah tatap muka yang telah ditetapkan oleh Kemdikbud, keterlibatan orang tua dalam pemberian izin pada anak untuk mengikuti sekolah tatap muka menjadi hal yang krusial. Perilaku pencarian informasi orang tua siswa di Malang terkait kebijakan sekolah tatap muka dipicu oleh kurangnya informasi yang pasti mengenai topik tersebut, banyaknya informasi yang simpang siur terkait pelaksanaan sekolah tatap muka serta kurangnya pengetahuan yang dimiliki oleh orang tua siswa terkait kebijakan yang ditetapkan. Proses pencarian informasi dapat dilakukan secara aktif dan pasif.

Pada perilaku pencarian informasi aktif, orang tua siswa lebih sering menggunakan sumber informasi melalui pihak sekolah (guru, wali kelas, kepala sekolah, $\mathrm{dsb}$ ) dan media daring. Sementara pencarian informasi secara pasif biasanya didapatkan melalui media daring, media sosial, ataupun informasi yang diberikan orang tua siswa lain melalui grup chat.

Informasi yang dianggap paling penting oleh orang tua siswa adalah mengenai kesiapan sekolah dalam pelaksanaan pembelajaran tatap muka dan bagaimana protokol kesehatan yang akan diterapkan selama pelaksanaan sekolah tatap muka. Adapun pihak sekolah menjadi sumber informasi yang paling sering dituju oleh orang tua siswa, sekaligus sumber informasi yang paling dipercaya.

Sementara itu, media sosial, orang tua siswa lainnya, dan anggota keluarga termasuk sumber informasi yang paling jarang digunakan sekaligus paling diragukan kebenarannya. Meski begitu, diskusi dengan orang tua siswa lainnya menjadi salah satu 
proses yang dipilih orang tua sebelum mengambil keputusan. Hal ini karena diskusi bersama orang tua siswa lainnya biasanya digunakan oleh orang tua untuk mendapatkan informasi tambahan setelah mendapatkan informasi utama dari media lain.

Dalam proses pencarian informasi, orang tua siswa biasanya melakukan komunikasi secara langsung dengan pihak yang dianggap berkepentingan dan bisa dipercaya seperit pihak sekolah. Selain itu, orang tua juga melakukan pencarian informasi di internet. Adapun tindak lanjut dari informasi yang didapatkan biasanya orang tua melakukan verifikasi serta pencarian data tambahan. Dalam hal ini kedudukan sumber informasi dapat berubah-ubah sebagai sumber informasi pertama ataupun tambahan. Namun hal ini tidak berkaitan dengan tingkat kepercayaan partisipan terhadap sumber informasi.

Berkaitan dengan pengambilan keputusan, mayoritas orang tua siswa memilih untuk menunda pengambilan keputusan jika informasi dirasa tidak cukup. Namun sebagian orang tua juga cenderung tetap mengambil keputusan karena khawatir proses pencarian informasi tidak ada habisnya. Sementara itu, orang tua yang merasa gagal mereduksi ketidakpastian dengan informasi-informasi yang didapatkan memilih untuk menyerahkan pengambilan keputusan pada pihak lain seperti pihak sekolah atau mengikuti kesepakatan orang tua siswa lainnya. Kegagalan ini salah satunya bisa disebabkan oleh information overload yang dialami oleh orang tua siswa.

\section{DAFTAR PUSTAKA}

Al-Ghamdi, K. M., \& Moussa, N. A. (2012). Internet use by the public to search for healthrelated information. International Journal of Medical Informatics, 81(6), 363-373. https://doi.org/10.1016/j.ijmedinf.2011.12.004

Anderson, K. J., \& Minke, K. M. (2007). Parent Involvement in Education: Toward an Understanding of Parents' Decision Making. The Journal of Educational Research, 100(5), 311-323. https://doi.org/10.3200/JOER.100.5.311-323

Assefa, S. G., \& Stansbury, M. (2018). Information seeking behavior of the poor: The study of parents' school choice decisions. Global Knowledge, Memory and Communication, 67(6/7), 377-395. https://doi.org/10.1108/GKMC-12-2017-0111

Avery, E. J., \& Park, S. (2021). Perceived Knowledge as [Protective] Power: Parents' Protective Efficacy, Information-Seeking, and Scrutiny during COVID-19. Health Communication, 36(1), 81-88. https://doi.org/10.1080/10410236.2020.1847438

Batley, S. (2007). Information Architecture for Information Professionals. Chandos Publishing. https://doi.org/10.1533/9781780631073

Bawden, D., \& Robinson, L. (2009). The dark side of information: Overload, anxiety and other paradoxes and pathologies. Journal of Information Science, 35(2), 180-191. https://doi.org/10.1177/0165551508095781

Case, D. O. (2007). Looking for information: A survey of research on information seeking, needs, and behavior (Edisi 2). Academic Press.

Chan, K. H., Panoch, J., Carroll, A., Wiehe, S., Cain, M. P., \& Frankel, R. (2020). Knowledge gaps and information seeking by parents about hypospadias. Journal of Pediatric Urology, 16(2). https://doi.org/10.1016/j.jpurol.2020.01.008

Crowley, J. L., \& High, A. C. (2018). Parents' information seeking during adolescent career development: A test of the theory of motivated information management. Journal of Applied Communication Research, 46(3), 348-367. https://doi.org/10.1080/00909882.2018.1468570

Foster, A. (2004). A nonlinear model of information-seeking behavior. Journal of the American Society for Information Science and Technology, 55(3), 228-237. https://doi.org/10.1002/asi.10359 
Garg, M. (2016). Information Seeking Behaviour Models: A Brief Introduction.

Hofstetter, C. R., Zuniga, S., \& Dozier, D. M. (2001). Media Self-Efficacy: Validation of a New Concept. Mass Communication and Society, 4(1), 61-76. https://doi.org/10.1207/S15327825MCS0401_05

Koja-Odongo, R., \& Mostert, R. (2013). Information seeking behaviour: A conceptual framework. South African Journal of Libraries and Information Science, 72(3). https://doi.org/10.7553/72-3-1112

Kuhlthau, C. C., Heinström, J., \& Todd, R. J. (2008). The 'information search process' revisited: Is the model still useful?

Kumar, P. R. S. (2015). Information Needs And Information Seeking Behaviour Of Faculty Of Malla Reddy Institute Of Technology \& Science, Telangana: A Study. 5(14).

Lwoga, E. T., \& Mosha, N. F. (2013). Information seeking behaviour of parents and caregivers of children with mental illness in Tanzania. Library Review, 62(8/9), 567584. https://doi.org/10.1108/LR-10-2012-0116

Neuman, L. W. (2014). Basics of Social Research: Qualitative \& quantitative approaches. Pearson Education Limited.

Nicholas, D., \& Marden, M. (1998). Parents and their Information Needs.: A case study: Parents of children under the age of five. Journal of Librarianship and Information Science, 30(1), 35-48.

Park, C. S. (2019). Does Too Much News on Social Media Discourage News Seeking? Mediating Role of News Efficacy Between Perceived News Overload and News Avoidance on Social Media. Social Media + Society, 5(3). https://doi.org/10.1177/2056305119872956

Plantin, L., \& Daneback, K. (2009). Parenthood, information and support on the internet. A literature review of research on parents and professionals online. BMC Family Practice, 10(1), 34. https://doi.org/10.1186/1471-2296-10-34

Schmitt, J. B., Debbelt, C. A., \& Schneider, F. M. (2018). Too much information? Predictors of information overload in the context of online news exposure. Information, Communication \& Society, 21(8), 1151-116. https://doi.org/10.1080/1369118X.2017.1305427

Wilcox, P. (1972). Parental Decision-Making: An Educational Necessity. Theory into Practice, 11(3), 178-182.

Wilson, T. D. (1999). Models in information behaviour research. Journal of Documentation, 55(3), 249-270. https://doi.org/10.1108/EUM0000000007145

Wimmer, R. D., \& Dominick, J. R. (2011). Mass media research: An introduction (Edisi 9). Cengage-Wadsworth. 